\title{
Implications of altitudinal migration for conservation strategies to protect tropical biodiversity: a case study of the Resplendent Quetzal Pharomacrus mocinno at Monteverde, Costa Rica
}

\author{
GEORGE V. N. POWELL and ROBIN D. BJORK
}

\section{Summary}

We documented habitat use by the Resplendent Quetzal Pharomacrus mocinno, a large frugivorous bird that breeds in cloud-forests in the highlands of Central America, to assess the adequacy of protection afforded to regional biodiversity by the Monteverde reserve complex, a protected natural area that includes most of the highland forests of the Tilarán mountain range in western Costa Rica. Our results demonstrated that this relatively large $(20,000 \mathrm{ha})$ protected natural area does not adequately protect the area's biodiversity. Through the use of radio-telemetry, we identified the areas on the Pacific slopes that are most critical to altitudinally migrating Quetzals. These forest patches are subject to deforestation and degradation and are rapidly becoming further isolated from other remaining forest. The possibility of the local extirpation of the Quetzal, through continued habitat loss on the Pacific slopes, presents an unusual dilemma for the region because the species is the major attraction for the local tourist industry which now includes over 80 businesses and annually generates over US\$5 million in local revenue. Therefore, its extirpation would seriously affect regional economic stability. In order to protect the Monteverde Quetzal population, we propose a regional conservation plan that depends on participation of local landowners to protect their remaining forest fragments and allows for the development of corridors to connect critical habitats as the focus of a regional conservation effort. While the ecological significance of the structure of corridors per se, versus other possible formats, is still being debated, we have selected the corridor format primarily because it is relatively easy for landowners to grasp the concept and the necessity for continuity of the corridor network. This recognition provides an important incentive for participation across property boundaries, promoting cooperation in a group effort rather than as isolated actions. Success of this cooperative plan will provide an example for grass-roots participation in buffer-zone management strategies elsewhere in the Neotropics.

Muchas especies de aves que habitan en las montañas de Centroamérica migran cada año de sus áreas de cría en las montañas, hacia bosques mas bajos en las 
vertientes, donde permanecen durante la estación no reproductiva. La mas famosa de estas especies es el Quetzal Resplandeciente Pharomacrus mocinno, una especie de gran importancia biológica, social y económica. Durante los años de 1989-1991 estudiamos el uso del hábitat por el quetzal en el área de conservación Arenal (ACA) en el oeste de Costa Rica. El estudio demostró que las reservas existentes en esta área, incluyendo la Reserva Biológica Monteverde y Bosque Eterno de los Niños, no protegen adecuadamente el hábitat del quetzal. Durante esta estudio de radio-telemetría, se colocaron sucesivamente radiotransmisores a 20 quetzales. Con el monitoreo de estas aves se descubrió que los quetzales tienen una compleja migración establecida que se lleva al cabo desde la Reserva Biológica Monteverde, en donde anidan, hasta bosques en las zonas bajas de ambas vertientes, Pacífico y Atlántico. Las áreas en la vertiente del Pacífico que fueron usadas por los quetzales durante su migración se encuentran fuera de las reservas y están fuertemente fragmentadas y frecuentemente degradadas. Para garantizar el futuro de los quetzales, deben llevarse a cabo planes que prevengan que los remanentes o parches de bosques comiencen a aislarse de la Reserva y convertirse en áreas inaceptables para los quetzales. Se propone un plan de conservación regional que proteja los parches de bosque, que son necesarios para garantizar una población estable de quetzal en el futuro. Para mantener conexiones entre estos fragmentos y la reserva, se ha designado un sistema de corredores que se creé proveerá suficientes vínculos para cumplir con el objetivo. Los corredores propuestos conectan las principales áreas de alimentación con la Reserva y en cada una de las otras áreas.

\section{Introduction}

Many species of birds that inhabit the mountains of Costa Rica migrate every year from their nesting areas in montane forests to forests further down the slopes where they remain during the non-breeding season (Stiles 1988, Loiselle and Blake 1991, Levey and Stiles this issue). Perhaps the best known altitudinal migrant in Central America is the Resplendent Quetzal Pharomachrus mocinno, a species that was revered by pre-Columbian cultures and is still considered a symbol of freedom in mountain forests. Quetzals migrate from their breeding areas in the lower montane rainforest (cloud-forest) life zone to pre-montane wet and moist life zones on the Pacific slopes for three to four months (JulyOctober), after which they move across the continental divide to the Atlantic slopes (Wheelright 1983, Powell and Bjork in press.; for life zones see Holdridge 1987). The Resplendent Quetzal is a frugivorous species that feeds primarily on Lauraceae fruit (Skutch 1944, Bowes et al. 1969, Wheelwright 1983, Wheelwright et al. 1984, Hernández and Obregón 1990). Quetzals range as disjunct populations in montane areas from southern Mexico through western Panama (Figure 1 ; LaBastille 1983). In this study we focused on the population that breeds in the Monteverde reserve complex and nearby farms in the Tilarán mountain range of west-central Costa Rica (Figure 1 ). The reserve complex consists of two privately owned protected natural areas, the Monteverde Cloud Forest Preserve, owned by the Tropical Science Center, a non-profit Costa Rican organization, and the International Children's Rainforest, owned by the Monteverde Conservation League, a local grass-roots non-profit organization. The reserve 


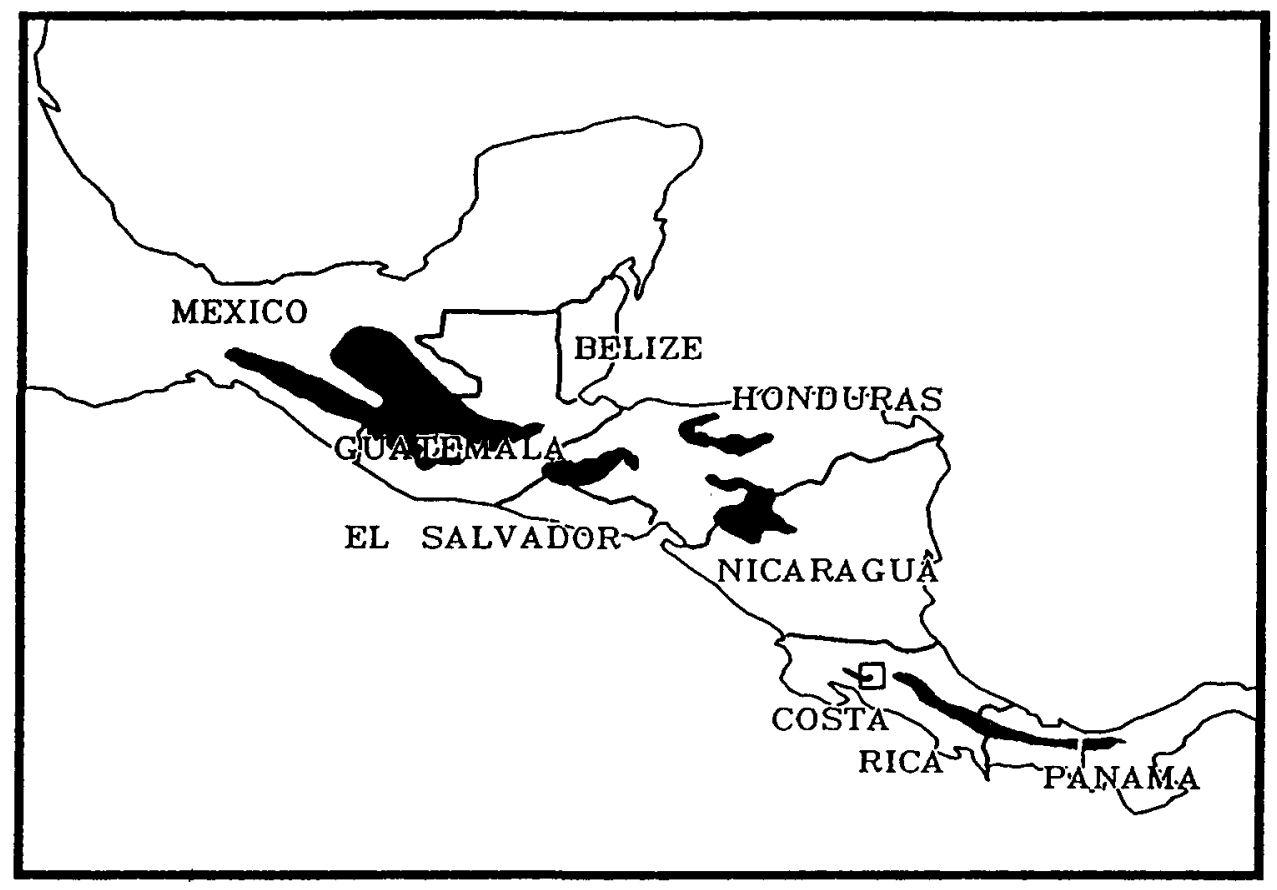

Figure 1. Geographic distribution of the two subspecies of Resplendent Quetzals in Central America (Pharomachrus mocinno mocinno between Mexico and Nicaragua and $P$. $m$. costaricensis in Costa Rica and Panama). The square marks our study site at Monteverde, Costa Rica.

complex totals more than 20,000 ha and straddles the continental divide in an area of high regional habitat heterogeneity, much of which is unrepresented in the protected area (Figure 2). The post-breeding migration by the Quetzals down the Pacific slopes takes them out of the area protected by the Monteverde reserve complex into an area that is populated by a rapidly expanding human population.

More than 40,000 tourists annually visit the Monteverde Cloud Forest Preserve, part of the Monteverde reserve complex, primarily in hopes of observing a Quetzal. These nature tourists have created an economy that includes hundreds of jobs for local residents. In the Monteverde area alone, there are $\mathbf{2 8}$ facilities providing lodging, eight restaurants, six riding stables, five craft shops and other miscellaneous support facilities (Rojas 1992). This tourist industry is generating over 400 full-time jobs and more than 140 part-time jobs; the latter are primarily women artisans who are significantly supplementing their families' incomes. However, while nature tourism has produced an economic boom for the local economy, its long-term stability is threatened by threats to the survival of the Quetzal itself. Because the Quetzals migrate off the Monteverde reserve complex into areas subjected to rapid human development, they are facing severe habitat loss and likely extirpation from the area if current trends are allowed to continue. Extirpation of the Quetzal population from the Monteverde area would not only be a tragic biological loss, but would seriously jeopardize regional economic stability. 


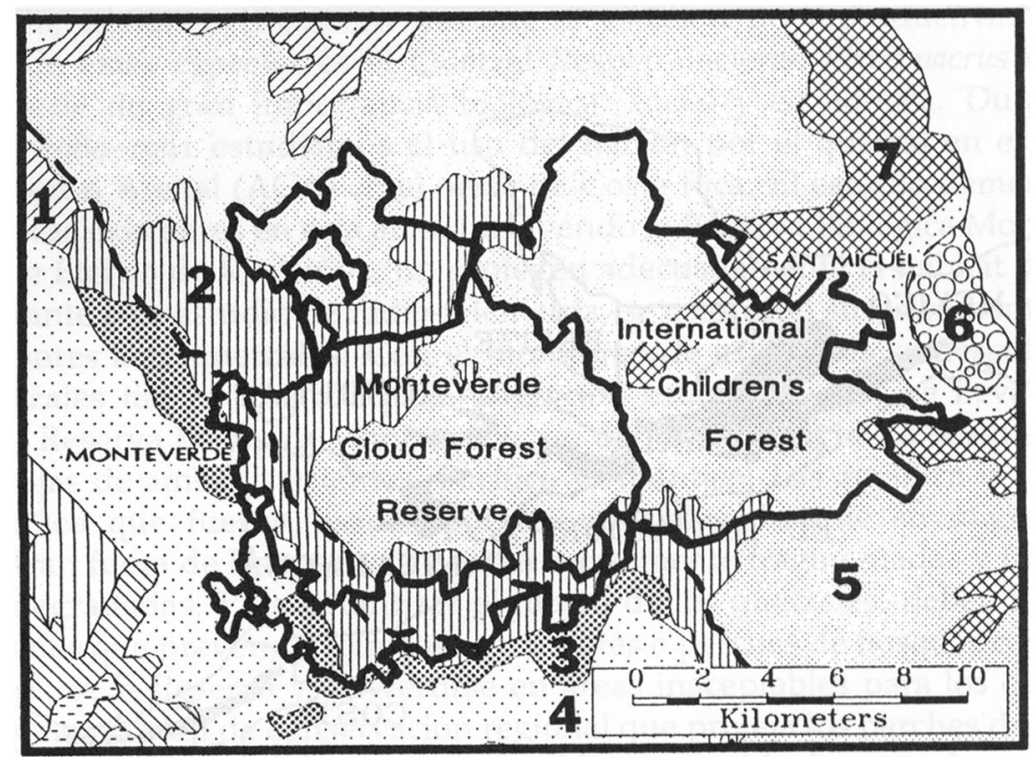

Figure 2. Monteverde reserve complex (solid bold line) in the lïlaran mountain range imposed upon the life zone (Tosi 1969) distributions in that area and the continental divide (broken line) separating the Atlantic drainage (upper right) from the Pacific drainage (lower left). Only two of the seven plant and animal communities are well represented in the reserve complex; the rest are being exposed to rapid degradation and clearing. The life zones are as follows: (1) tropical moist/pre-montane belt transition; (2) pre-montane wet forest; (3) lower montane wet forest; (4) lower montane rainforest; (5) pre-montane rainforest; (6) tropical wet forest/pre-montane belt transition; (7) tropical wet forest.

To protect critical Pacific slope habitat for the Monteverde Quetzal population, it was necessary to identify the principal habitats they use during that phase of their annual cycle. The purpose of this study, therefore, was to collect detailed data on habitat use by migratory Quetzals on the Pacific slopes, and to use this information to design a regional land-use plan that included the necessary protection for those critical forests.

\section{Methods}

To identify the forest habitats that are critical to the survival of Quetzals, we used radio telemetry to track them throughout their annual cycle. Radiotransmitters, constructed by Holohil Systems Ltd, Ontario, Canada, were placed on the Quetzals with a harness in the form of a backpack. The harness was composed of straps of lightweight Teflon ribbon that ran from the forward end of the transmitter, crossing on the breast, passing under the wings, and attaching to the rear end of the transmitter on the lower back. The rear attachment of the harness was secured with a light cotton thread which could deteriorate and allow the transmitter to fall off after it ceased to function. The entire package weighed about $6 \mathrm{~g}$ or about $3 \%$ of the $200 \pm 10 \mathrm{~g}$ birds. 
Table 1. Quetzals fitted with radio-transmitters at Monteverde, 1989 and 1990

\begin{tabular}{ccccc}
\hline Bird I.D. & Frequency & Date banded & Sex & Mate I.D. \\
\hline YEAR ONE (1989) & & & & \\
1 & 922 & 12 May & M & $?$ \\
2 & 955 & 12 May & F & $?$ \\
3 & 997 & 23 June & M & $?$ \\
4 & 957 & 10 July & M & $?$ \\
5 & 965 & 12 July & F & 959 \\
6 & 959 & 12 July & M & 965 \\
7 & 939 & 14 July & M & $?$ \\
YEAR TWO (1990) & & & & \\
8 & 858 & 29 April & F & $?$ \\
4 & 862 & 2 May & M & 888 \\
10 & 888 & 4 May & F & 862 \\
5 & 890 & 4 May & F & 886 \\
6 & 886 & 4 May & M & 890 \\
11 & 878 & 8 May & M & 864 \\
12 & 864 & 11 May & F & 878 \\
13 & 884 & 25 May & M & $?$ \\
3 & 874 & 26 May & M & 882 \\
14 & 882 & 31 May & F & 874 \\
15 & 879 & 10 June & F & $?$ \\
16 & 860 & 30 June & M & 858 \\
\hline
\end{tabular}

We used two methods to capture the Quetzals: mist-nets placed in front of fruiting trees, and nest-traps. The nest-trap consisted of a small hoop net $(0.4 \mathrm{~m}$ in diameter) on an extendable pole that could be placed in front of an active nest after a bird had entered it to feed its young. Captured Quetzals were weighed, fitted with transmitters and released within 45 to 60 minutes.

Movements of the Quetzals were monitored using a portable receiver and hand-held directional " $\mathrm{H}$ " antenna, which gave us a ground detection range of $1-2 \mathrm{~km}$. Our observation protocol was designed to collect data on two scales of movement: local (micro), and long-distance (migratory). We prepared detailed maps of forest distribution and topography of the study area on a geographical information system (CAMRIS: Ford 1989), using low-level aerial photographs and 1:50,000 topographical quadrangles obtained from the Costa Rican government. Locations of radio-tagged birds were plotted $( \pm 25 \mathrm{~m})$ on these maps, enabling us to determine movement pattern, elevational changes and distribution of forests used by the birds.

We checked all radio-tagged individuals on a daily basis to verify their presence in the local area. After these checks, two individuals were selected, based on days lapsed since previous observation, and observed for three to four hours each to collect local movement data. During these observations the birds were followed and data on habitat use, food selection, seed regurgitation and social interactions were collected.

\section{Results}

During two years of study we successfully placed radio-transmitters on 19 Quetzals; seven during the first year and 12 (including four recaptures) during the second (Table 1). Initially, we placed transmitters on two individuals and 


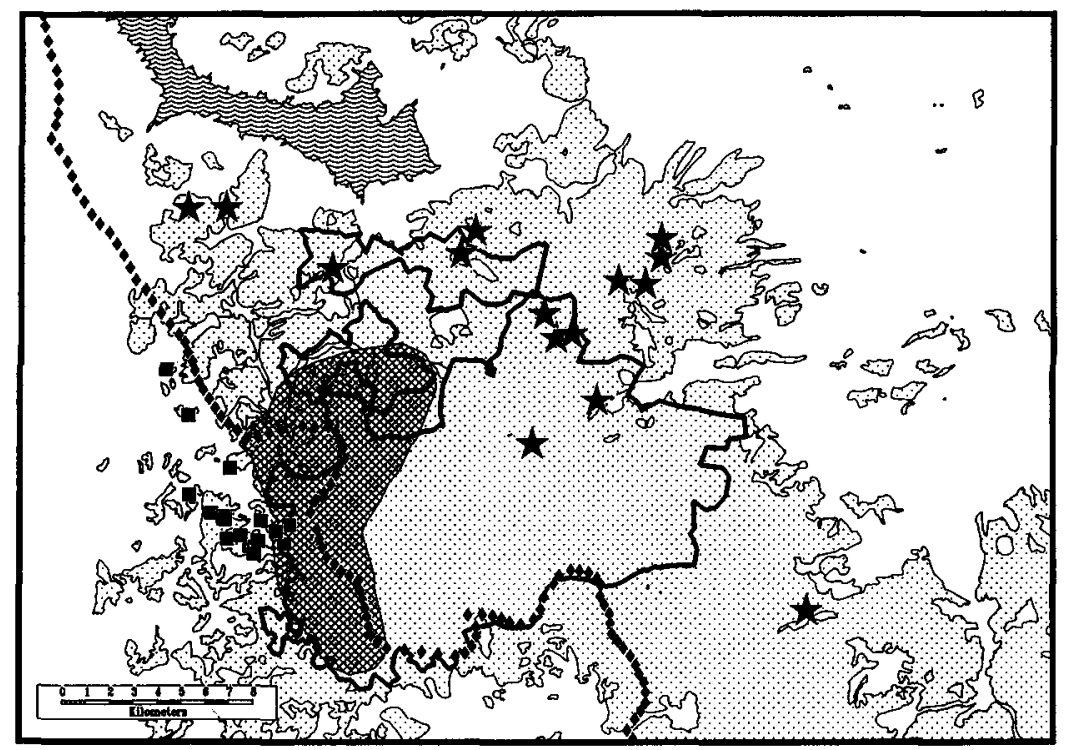

Figure 3. Locations of radio-tagged Resplendent Quetzals in Costa Rica during their sequential migrations from their breeding area (hatched area) first down the Pacific slope (squares) and then across the continental divide and down the Atlantic slope (stars). The Quetzal locations denote foci of home ranges of individuals that remained in that area for one to three months.

observed them for a month to be certain that there were no negative impacts. After concluding that the birds continued to feed without observable interference by the transmitters, we continued capturing and harnessing birds. Premature failure of four transmitters during the first year and five during the second prevented us from obtaining complete movement records on those individuals. However, all but two of these birds had already moved off their breeding ranges before their transmitters failed, and in all cases we were able to monitor their presence and absence on the breeding area by using the transmitter as a marker.

With the radio-tagged birds, we were able to follow the Quetzals' migrations precisely, from their nesting areas into forest habitats lower down on both the Pacific and Atlantic slopes (Figure 3). They nested primarily in the Monteverde Cloud Forest Preserve from February through June. At the end of the first breeding season, all but one of the radio-tagged individuals left the breeding area and moved down the Pacific slope into small fragments of pre-montane moist forest between 1,300 and $1,450 \mathrm{~m}$ elevation; during the second year of the study, all birds had moved off the breeding range into the lower montane and pre-montane wet forests between 1,100 and 1,350 m elevation by July. In both years, they remained in these areas feeding primarily on Lauraceae fruit until October or November. At that time all individuals that had been on the Pacific slopes, plus the individual that had remained on its breeding range the first year, migrated across the continental divide and down the Atlantic gopes into pre-montane rainforest at 700 to $1,200 \mathrm{~m}$ elevation. They remained in this area until returning to their breeding ranges in the cloud-forest in January. 
These data demonstrated that the existing Monteverde reserve complex does not adequately protect the Quetzal's year-round habitat. Unprotected forested areas on both the Atlantic and Pacific slopes are critical to the Quetzals between July and January when they migrate into these areas. Subsequent research in these areas is showing that many of the unprotected habitats used by the Quetzals harbour plants and animals that are unrepresented or poorly represented in the reserve complex (C. Guindon unpublished data). Therefore, protecting these areas is not only important for the future survival of the Quetzal, but also for many other organisms.

Unless protection is extended to the critical habitats used by migrating Quetzals, the population of the species will probably disappear from the area. Steps have been taken by the Monteverde Conservation League and, more recently, the government of Costa Rica to purchase critical habitat on the Atlantic slope where the forest is still in large blocks and relatively inexpensive.

Conserving critical habitats on the Pacific slope requires a different solution. These forests, which are largely unrepresented in the Monteverde reserve complex (Figure 4), are heavily fragmented (Figure 5) and highly threatened by development. Included within this critical zone are 13 human communities totalling more than 2,000 families. In most cases, forest patches that remain in these areas are not available for purchase because they are typically interwoven in a matrix of developed land that includes multiple owners. If they are available for purchase, the commercial value of developed lands that must be purchased in conjunction with the forest patches makes the transactions prohibitively expensive. Consequently, we looked to alternative approaches including

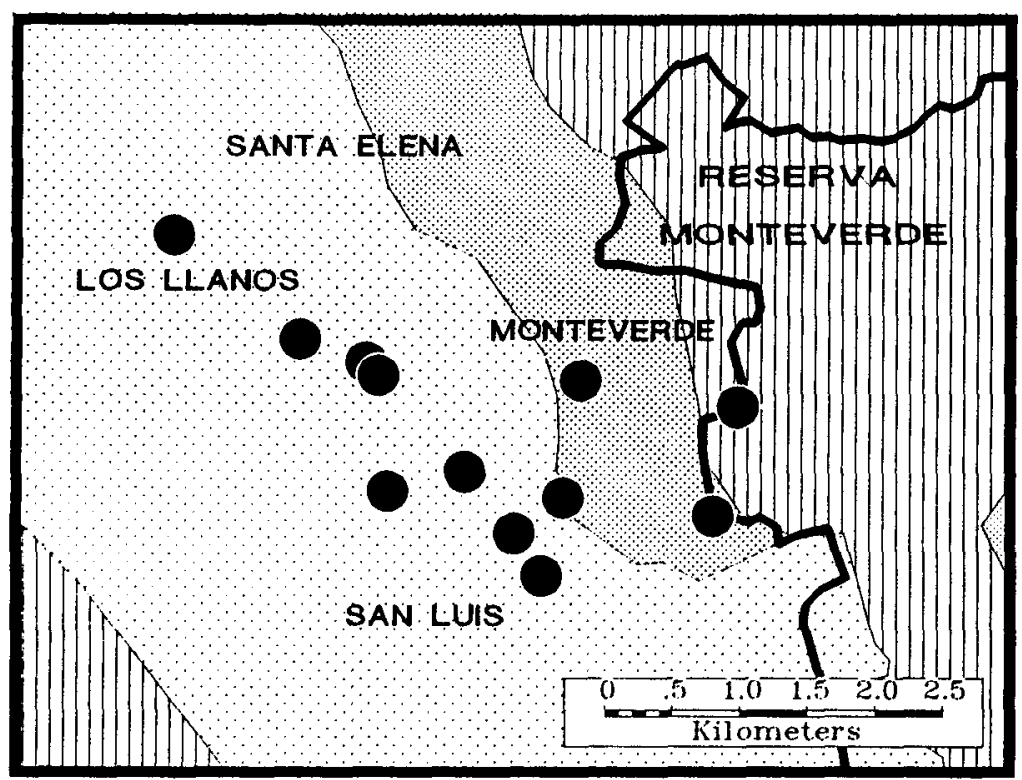

Figure 4. Locations of radio-tagged Quetzals on the Pacific slope superimposed on life zone distributions as denoted by Tosi (1969). The figure demonstrates the dependency of Quetzals on habitats unrepresented in the Monteverde reserve (solid line). 


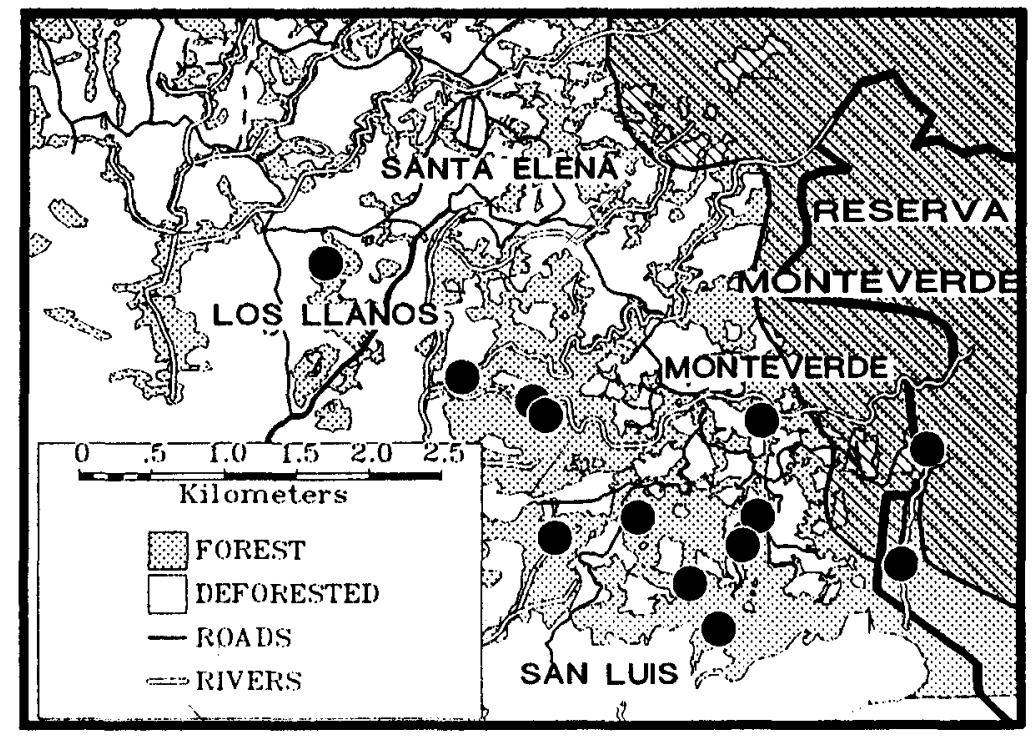

Figure 5. Locations of radio-tagged Quetzals on the Pacific slope superimposed on the forest distribution. While the Quetzal's breeding area (hatched area) is well represented within the reserve (bold line), the Pacific locations are in unprotected forest patches that are subject to degradation and clearing.

cooperative agreements, conservation easements and leases with the landowners to protect these areas.

\section{Discussion}

Conserving critical forest habitat on private land: a strategic plan

After identifying the areas on the Pacific slope outside the Monteverde reserve complex that are used by migratory Quetzals, we developed a regional habitat protection plan that would maintain and upgrade remaining forest patches in those areas. The development and implementation of the plan has been three-fold.

First, we prioritized all remaining forest patches on the study area based on utilization by Quetzals, interannual availability of fruit, and amount of forest remaining nearby. Second, using our maps created on the CAMRIS geographic information system, we delineated the most important existing forest patches and designed, as a pilot project, a system of corridors in the Monteverde-Santa Elena-Los Llanos area that would interconnect the patches and in turn connect the patches with the reserve complex. Included in the initial network are three short corridors through the Monteverde area and a longer corridor through the Santa Elena and Los Llanos areas (Figure 6). Ideally, corridors will be at least $100 \mathrm{~m}$ wide and will connect to the Monteverde reserve complex, critical feeding areas or other corridors. While the ecological significance of the structure of corridors per se, as against other possible formats, is still being debated (Noss and Harris 1986, Simberloff and Cox 1987, Noss 1990), we have selected the 


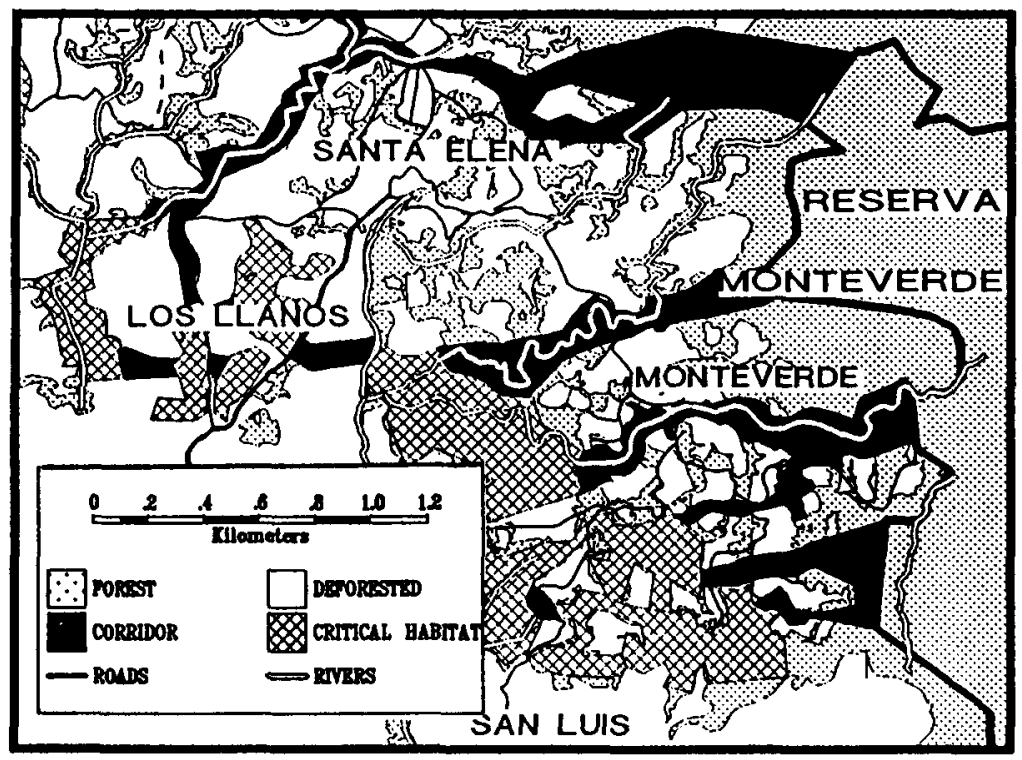

Figure 6. Distribution of forest patches recognized as important habitat (hatched areas) for Quetzals while they are on the Pacific slopes, and proposed corridors (dark areas) to connect these habitats to the Monteverde reserve (bold line).

corridor format because of additional considerations. The structure of corridors across altitudinal gradients may facilitate altitudinal movements by the Quetzals as well as those of other altitudinal migrants native to the area. Corridors also allow us to counter most easily wind and fire damage, two major negative forces on forest patch quality in the area. Furthermore, it is relatively easy for landowners to grasp the concept of corridors and the necessity for continuity in the corridor network. This recognition provides an important incentive for participation across property boundaries, promoting cooperation in a group effort rather than as isolated actions.

\section{The strategic plan}

Establishing these corridors will require (a) eliminating or neutralizing forces that are currently causing deterioration in remaining forest fragments, and (b) the selective reforestation of cleared land within the proposed corridors to reconnect the fragments. These modifications will be achieved largely through cooperative agreements with landowners. The goal of maintaining forest fragments within the buffer directly serves the interests of the landowners because it will protect their sources of water, reduce soil erosion, reduce wind damage to their agricultural areas, and help them to maintain a sustainable source of forest resources for their domestic uses. Wood for fencing, barn construction or repairs, etc., is becoming increasingly scarce on local farms, and prohibitively expensive to purchase from the outside. Many of the trees that are valuable as food sources for wildlife are also primary timber sources. Therefore, our project 
proposes to establish buffers around existing fragments and to reforest gaps in corridors with selected native tree species that will increase food resources for wildlife while providing a timber source for the landowner. Finally, a goal of the project will be to develop sustained management practices for the corridors.

To achieve these goals, we developed a strategic plan with the following major elements:

1. conservation easements to protect forest patches;

2. a cooperative programme with landowners to protect critical wildlife feeding areas and maintain forest corridors through the following activities:

(a) educating owners of values of forest patches,

(b) insulating forest patches from further degradation by livestock,

(c) providing alternatives to wooden fence posts, the need for which leads

to serious degradation of forest patches,

(d) reforesting gaps in corridors with native species that supply both food for wildlife and timber for landowners' domestic needs,

(e) experimenting with techniques to manage forest patches to maintain their wildlife value while allowing limited extraction of trees for domestic use by landowners;

3. creating economic incentives for landowners to conserve forest.

Implementation of the plan to protect private forest patches that are important to migrating Quetzals is in the early stages. The following presents a summary of developments to date.

\section{Conservation easements}

The discovery that Quetzals migrating from the protected area of the Monteverde reserve complex depended on areas with some of the highest land values within the rapidly growing surrounding communities made it clear that alternatives other than direct purchase were necessary to preserve these sites. This realization led us to investigate the possibility of using conservation easements to protect remaining forest fragments. Through the Environmental and Natural Resources Law Center (CEDARENA) we learned that the conservation easement concept has not been applied in Costa Rica or the rest of Central America. Lawyers at CEDARENA subsequently determined from a study of legal precedent that right-of-way law (servidumbre) should allow a piece of property to be encumbered with permanent conservation easements. To test the use of servidumbre, CEDARENA involved The Nature Conservancy, which purchased a farm close to the Monteverde reserve that was heavily used by migrating Quetzals, placed deed restrictions on the farm and is now preparing to resell it to a private school. This transaction marked the first international use of The Nature Conservancy's revolving fund to buy habitat and the first application of a conservation easement in Costa Rica. To date, the Costa Rican supreme court has prevented the government from restricting private land on the basis of constitutionality; however, it is expected that The Nature Conservancy's easements will be declared legal because the restrictions are established voluntarily by the landowner, in this case The Nature Conservancy, and without government intervention. 


\section{Cooperative forest protection and management}

With the assistance of personnel from the Monteverde Conservation League and the Tropical Science Center, we developed a five-part plan to protect forest fragments that are important to migrating Quetzals by working cooperatively with landowners.

1. An outreach programme with landowners to instil in them the values of maintaining forest patches on their farms. These values include sustainable sources of timber for domestic use, wind breaks, watershed protection, erosion control and wildlife value.

2. A cooperative programme with landowners to protect forest fragments from further degradation by cattle. Participating landowners are supplied with fencing materials while they supply labour to construct fences around existing forest patches that have been identified as major Quetzal feeding areas and that are within the planned corridors (Figure 4).

3. Reducing/eliminating the need to cut wooden posts by providing landowners with alternative materials. The extraction of trees for fence posts is one of the most serious causes of degradation of forest fragments in the buffer-zone. To reduce or eliminate this pressure, the project will provide area landowners with live and concrete fence posts. Live fence posts are posts that are started from cuttings of selected tree species that will take root, thereby producing a permanent fence post which in turn produces more cuttings for fence maintenance or extension. The use of live fence posts will ultimately eliminate the need for traditional wooden posts. Because live fence posts require about one year after planting to be sufficiently established to function as posts, it is necessary to place cement posts at intervals along new fences. This will require the establishment of an experimental project with live posts to identify the appropriate native species and the techniques for planting them.

4. A cooperative project with landowners to reforest cleared areas within corridors with native species that are valuable for both wildlife and timber. By selecting species that are valuable for timber (Lauraceae, the primary food of many frugivorous birds, are also important timber species), landowners will be able to reforest portions of their land as an investment for future domestic lumber needs. Three reforestation techniques will be available for use in the corridors depending on site specifics. The first technique will involve fencing the area and allowing natural regeneration to occur; the second will involve fencing and then planting seedlings of primary (shade-tolerant) species which have been started in a nursery; and the third will involve planting fast-growing secondary species to create conditions more favourable for the establishment of primary species, which will be planted one to two years later.

5. A research programme into techniques of limited harvesting of timber for domestic use without degrading the habitat value of the forest patches. Three procedures are proposed to allow for the extraction of forest products for domestic use while maintaining habitat quality within the corridors: (a) minimization of removal of standing trees through the use of an education outreach programme to heighten landowner awareness of the value of their forest fragments in the context of their other land uses and of maintaining regional biodiversity; (b) minimization of the impact of removal by coring trees prior to cutting, to assure that they are 
sound, and by carefully directing their fall; and (c) assuring the replacement of the species removed by planting a seedling within the resulting lightgap.

The cooperative programme outlined above is being implemented by the Monteverde Conservation League and the Tropical Science Center with financial support from RARE Center. The programme they have begun will function as a pilot effort that will be modified and expanded in accordance with its success. Our intention is to extend the corridors to an additional nine communities on the Pacific slope that are within the migratory range of the Quetzal.

\section{Economic incentives for conserving private forests}

The growth of natural history tourism in the Monteverde area has created new opportunities for generating income from privately owned forest. Because these lower elevation forests are in life zones that are not or poorly represented in the Monteverde reserve complex (Figure 4), they support many plant and animal species, including migratory Quetzals, Three-wattled Bellbirds Procnias tricarunculatus and Keel-billed Toucans Ramphastos sulfuratus, that are absent from the reserve or in areas inaccessible to tourists. Birdwatchers, a significant component of the more than 40,00o tourists that visit Monteverde annually, are eager to gain access to the lower forest fragments, particularly when Quetzals can be found there and nowhere else, and can be charged a modest entrance fee (US $\$ 5$ is currently levied by some landowners) once minimum infrastructure in the form of simple trails has been provided. In addition to their value to birdwatchers, forest fragments can provide scenic trails for horseback riding, which is prohibited on the reserve.

During the past two years, seven landowners established simple trails on their farms to service natural history tourists, and have been successful in attracting users. Demand for this service is expected to grow in the future, particularly because the reserve management has recently placed a limit of 100 persons on the reserve at one time. Consequently, tourists are being forced to look for alternatives for several hours until access becomes available. As yet no-one has been prevented from entering the reserve for an entire day, but that event is likely to happen as early as next season. Through concern over the prospect of tourists having to wait too long before gaining entrance or of being turned away altogether, the reserve is developing plans to establish a Welcome Center several miles from its entrance. A primary function of the Welcome Center will be to manage the flow of tourists, directing the overflow to other local access-points to the forest, most of which are private.

\section{Conclusions}

Maintaining existing forest patches in life zones adjacent to and unrepresented in the Monteverde reserve complex must be a high priority for both the reserve management and the local communities, lest they suffer the economic consequences of extirpating the Resplendent Quetzal. We have designed a system of priority areas and corridors that should provide sufficient linkages to achieve that goal (Figure 6). We feel there is great potential for protecting regional biodiversity through a diversified buffer-zone management programme that 
focuses on protecting forest patches by cooperative conservation and reforestation programmes with local landowners and limited purchasing of key parcels that cannot otherwise be protected.

Because the continued survival of a Quetzal population in the Monteverde area is an economic as well as environmental issue, implementation of this buffer-zone management plan should not only involve area conservation organizations, but also organizations and enterprises involved in management of tourism and regional planning as well as relevant municipal governments. Only through this level of cooperation can the task of implementing a plan that conserves regional biodiversity, including the Quetzals themselves, succeed.

\section{Acknowledgements}

The success of our telemetry work was dependent on outstanding field assistance from Sergio Barrios, Maria Lourdes de Avila and Vicente Espinosa. Benito Guindon assisted with project management and various aspects of the fieldwork, and Carlos Guindon and Marco Vinicio Zamora helped us develop the forest patch conservation plan. This work was supported by grants from the Pew Charitable Trusts and the W. Alton Jones Foundation.

\section{References}

Bowes, A., LaBastille, A. and Allen, D. G. (1969) Biology and conservation of the Quetzal. Biol. Conserv. 1: 297-306.

Ford, R. G. (1989) CAMRIS: computer aided mapping and resource inventory system. Unpublished.

Hernández, M. de L. A. and Obregón, V. H. H. (1990) Contribución a la biología y distribución del quetzal Pharomachrus mocinno mocinno en la reserva "El Triunfo". Chiapas, Mexico: Universidad Nacional Autónoma de México (unpublished thesis).

Holdridge, L. R. (1987) Life zone ecology. Revised edition. San José, Costa Rica: Tropical Science Center.

LaBastille, A. (1983) Pharomachrus mocinno (Quetzal). Pp,599-601 in D. H. Janzen, ed. Costa Rican natural history. Chicago: University of Chicago Press.

Loiselle, B. A. and Blake, J. G. (1991) Temporal variation in birds and fruits along an elevational gradient in Costa Rica. Ecology 72: 180-193.

Noss, R. F. (1990) From endangered species to biodiversity. In K. Kohm, ed. Balancing on the brink: a retrospective on the Endangered Species Act. Washington, D.C.: Island Press.

Noss, R. F. and Harris, L. D. (1986) Nodes, networks, and MUMs: preserving diversity at all scales. Environ. Mgmt. 10: 299-309.

Powell, G. V. N. and Bjork, R. D. (in press) Conserving tropical biodiversity: implications of intratropical migration on design theory for protected natural areas. Conserv. Biol.

Rojas, C. M. (1992) Monteverde: estudio inicial de los nexos entre la reserva, el turismo y la comunidad local. Unpublished.

Simberloff, D. and Cox, J. (1987) Consequences and costs of conservation corridors. Conserv. Biol. 1: 63-71.

Skutch, A. F. (1944) Life history of the quetzal. Condor 46: 213-235.

Stiles, F. G. (1988) Altitudinal movements of bird on the Caribbean slope of Costa Rica: implications for conservation. Pp.243-258 in F. Almeda and C. M. Pringle, eds. Tropical rainforests: diversity and conservation. San Francisco, CA: California Academy of Sciences. 
Tosi, J. A. (1969) Mapa ecológico, República de Costa Rica. San José, Costa Rica: Tropical Science Center.

Wheelwright, N. T. (1983) Fruits and the ecology of resplendent quetzals. Auk 100: 286301.

Wheelwright, N. T., Haber, W. A., Murray, K. G. and Guindon, C. (1984) Tropical fruit-eating birds and their food plants: a survey of a Costa Rican Lower Montane Forest. Biotropica 16: 173-192.

GEORGE V. N. POWELL

RARE Center for Tropical Conservation, 1616 Walnut Street, Suite 911, Philadelphia, PA 19103, U.S.A.

ROBIN D. BJORK

National Audubon Society, 115 Indian Mount Trail, Tavernier, FL 33070, U.S.A. 